\title{
关于概念图在高中生物学中的应用研究
}

\author{
周星 \\ 江苏省高邮市第一中学 \\ DOI:10.32629/jief.v2i11.2379
}

[摘 要] 美国在上个世纪首次提出概念图的概念。其作为一种有效地教学方式, 在我国教育改革的过程中逐渐被引用。对教师来说, 概念图 能够把繁琐的知识有效地组合在一起, 提高课堂的教学效果。对学生来讲, 通过绘制概念图能够使复杂的知识直接的呈现出来, 利于掌握各 个知识点的联系。这篇文章主要就是探讨概念图在高中生物课堂上的应用。

[关键词] 概念图; 生物教学; 应用研究

中图分类号：G633.91 文献标识码：A

在高中阶段, 生物学科的知识变得更加深入, 如果学生上课不集中 注意力听讲, 就有可能理解不了书本上的内容。但概念图引用到教学中 之后, 学生可以根据书上的图和老师画的图自己学习, 概念图不仅包含 着各种专业名词的概念, 而且各个知识点之间的联系也非常的清楚, 学 生学起来没什么困难。

\section{1 概念图应用在高中生物课堂中的意义}

1.1 有利于优化知识的结构

从教师的角度看, 教师每天的工作量是不轻松的, 在给学生讲授知 识时要提前备课, 还要面临着复杂的工作要求, 生物知识多而复杂, 不 能够绝对保证教学的全面性。但如果教师运用概念图来进行教学活动, 就能够通过对概念图的讲解, 充分地调动大脑中储备的知识, 引导学生 从不同的角度思考问题, 拓宽学生掌握的知识范围。比如, 教师在讲授 苏教版必修二 《DNA 的结构和 DNA 的复制》时, 如果只是在讲台上一昧 地口头描述 DNA 的分子结构, 学生是根本理解不了的。这时教师一定要 采取行动, 拿起粉笔在黑板上画出大致的结构图, 引起学生的注意力, 让他们进行观察并思考 DNA 分子双螺旋结构的特点都有什么。同时也可 以画出 DNA 分子的平面结构图, 引导学生看图的时候明白什么叫碱基互 补配对原则。这样直接画图有利于理清知识的脉络, 帮助教师可以迅速 进入教师角色, 不断优化自身的知识结构, 选择合适的教学方式提高教 学效果。从学生的角度来看, 在学习 DNA 的分子结构时, 经过教师的指 导和自身不断的练习, 学生可以充分掌握 DNA 的结构构成, 同时还可以 与学过的《探索遗传物质的过程》这一课知识点联系在一起, 打破蛋白 质是遗传物质的观点, 在思考的过程中, 不断地使自身的知识体系得到 完善。

\section{2 有利于提高学生的学习兴趣}

在传统的课堂上, 教师更加重视本节课的教学内容有没有完成, 对 学生的课堂参与并没有很在意, 在教师看来, 学生只要课堂上认真听讲, 课下好好记忆就能很好的掌握知识内容。但现实结果显示, 这种想法是 错误的。与之相反, 在绘制概念图的过程中, 学生需要开动自己的大脑, 调动脑中所储备的知识, 主动参与到这个过程。当学生在这个过程中逐 渐找到自信、发现自身的价值, 那么在课堂上就会变得非常积极, 课堂 的气氛就会变得轻松许多。此外, 概念图能够把很多复杂的知识用简单 的边框箭头表示出来, 帮助降低学生的学习难度, 学生学习来没那么难 了, 快乐也就多了, 对学习也就越来越充满兴趣了。

1.3 有利于学生学习方法多元化

生物和其他学科比较起来算是很难的, 因为生物知识比较抽象, 专 业名词比较多, 概念也比较难懂。高中生要想学好生物这门学科, 就必 须选择适合自己的学习方法。概念图作为一种新式的学习方法, 它能够 加强学生和老师同学之间的交流, 在互动的过程中取长补短, 有效率的
学习。同时, 在这个过程中, 学生也可以根据图上的内容进行思考, 使 自己的思维得到发散。总之, 概念图在高中生物中的应用是非常重要的, 它为学生提供了别样的学习方法, 使学生的学习方法的种类变多, 给了 学生很大的参考空间。

\section{2 概念图在高中生物教学中的应用策略}

2.1 应用到教师的教学设计中

要想提高学生的学习效率, 教师一定要好好地备课, 把课堂上要讲 的内容设计好, 争取课堂上的每一分每一秒都不会被浪费掉。教师在进 行教学设计时, 要充分考虑到教学过程中的各个方面, 从整体上画出概 念图, 帮助教师结合学生自身的知识水平选择合适的教学方式, 同时也 帮助教师在下课之后进行反思, 在不足中进步, 保证教学的质量。

2.2 应用到学生的学习活动中

随着教育改革的开展, 学生在课堂上的地位也变得很高, 新的教育 目标强调教师要帮助学生学会学习, 尤其是要学会自己学习。概念图在 课程中的应用是实现教学目标最有用的方式之一。比如, 教师可以引导 学生对知识内容进行大胆的猜想, 采用科学的方法进行探究式的自主学 习。学生可以把将要实现的步骤绘制成概念图, 为实验探究提供指导, 保证实验探究过程的顺利。再比如, 教师也可以鼓励学生自己学习, 引 导学生考虑各种情况画出概念图, 帮助学生明确自己的学习任务, 能够 在概念图的指导下毫不费力地学习。

2.3 应用到教学评价中

将概念图应用到教学评价当中, 能够帮助教师从不同的角度出发, 发现学生的优势和不足。在对学生进行评价时, 能够综合考虑学生的各 个方面表现, 对其进行合理的评价, 增强学生的自信心, 提高学生学习 的积极性。同时在概念图的指导下, 教师在进行自我的教学评价时能够 及时反思, 发现自己的不足之处并改正, 创新教学方式, 提高教学的质 量。

\section{3 结束语}

把概念图应用到高中生物的课堂中能够帮助学生进行有意义的学 习, 但这种教学方式不是唯一有效的, 因此教师要重视与其他教学方式 的结合, 寻找多种有效地教学方式, 提高教学效果。

\section{[参考文献]}

[1] 李成双. 微课在高中生物教学中的创新应用 [J]. 学周 刊,2020(30):127-128.

[2]彭春霞.核心素养背景下的高中生物教学研究和探索 [J]. 知识窗 (教师版),2020(09):122.

[3]张克风.生活实践在高中生物翻转课堂中的应用 [J].科学咨询 (教 育科研),2020(10):263. 